Western North American Naturalist 69(3), (C) 2009, pp. 285-294

\title{
BURROW OCCUPANCY PATTERNS OF THE WESTERN BURROWING OWL IN SOUTHERN NEVADA
}

\author{
Paul D. Greger ${ }^{1,2}$ and Derek B. Hall ${ }^{1}$
}

\begin{abstract}
Understanding long-term patterns of burrow occupancy for the Western Burrowing Owl (Athene cunicularia hypugaea) is necessary for the conservation of this species, especially in arid, desert ecosystems where burrow occupancy data are lacking. Monthly burrow monitoring was conducted over a 4-year period (1997-2001) in southern Nevada to determine burrow occupancy patterns of Burrowing Owls and to evaluate the effects of burrow type and desert region on burrow occupancy. Burrow occupancy occurred year-round and was most consistent in the Transition region and tended to be lowest in the Mojave Desert region. Peak burrow occupancy occurred during March through May, followed by a gradual decline in occupancy through the summer and fall until January and February, when occupancy was lowest. Occupancy was significantly higher at sites with both culvert and pipe burrows than at sites with earthen burrows in disturbed habitat or earthen burrows in natural habitat. Breeding-season occupancy was not significantly higher in wetter, cooler portions (e.g., Great Basin desert region) of the study area. Results suggest that occupancy is influenced by habitat features—such as suitable burrows in open areas with low vegetation-and climatic regime.
\end{abstract}

Key words: Athene cunicularia hypugaea, Western Burrowing Owl, burrow occupancy, burrow type, southern Nevada, Great Basin Desert, Mojave Desert.

The Western Burrowing Owl (Athene cunicularia hypugaea) is declining throughout much of its range and is currently considered a National Bird of Conservation Concern by the U.S. Fish and Wildlife Service (Klute et al. 2003). In order to conserve this species, it is important to understand long-term patterns of burrow use (i.e., occupancy) so burrows with high-use potential can be protected and impacts to burrows from land use and land management decisions can be evaluated. Although researchers have investigated burrow use in various ecosystems (Coulombe 1971, Thomsen 1971, Rich 1986, Belthoff and King 1997, Botelho and Arrowood 1998, Lantz et al. 2007), information on burrow use in arid, desert ecosystems is lacking. Furthermore, while some investigators have evaluated long-term use and reuse of individual burrows (Rich 1984, Lutz and Plumpton 1999, Desmond et al. 2000, Belthoff and Smith 2003, Holmes et al. 2003), none have conducted year-round monthly burrow monitoring. Multiyear patterns of Burrowing Owl occupancy in deserts may be important, as this information could describe patterns of owl ecology that are different from those found in other ecosystems. Year-long monitoring of burrow sites may also detect evidence for the localized or regional movements of owls.

Evaluating burrow usage in different types of burrows may be important because length of occupancy, and therefore quality of burrows, may vary with burrow type or site. Botelho and Arrowood (1996) found that Burrowing Owl productivity (i.e., number of nestlings and fledglings) varied significantly between natural and disturbed sites, indicating that differences in burrow type or site were important. Also, information gained from owl use of different burrow types may be useful in developing new artificial burrows or in designing the burrow site.

Rundel and Gibson (1996) reported that higher bird densities and more bird breeding occurred in wet years and within wetter portions of the Nevada Test Site (NTS) and that yearly variability in desert bird populations is highly dependent on climatic factors. Therefore, if this pattern follows for owls as for other birds, we would predict higher Burrowing Owl occupancy in wetter, cooler areas of the NTS as compared to the lower desert. 
This study was conducted to (1) determine year-round occupancy patterns of Burrowing Owls over multiple years in an arid, desert ecosystem, (2) evaluate burrow occupancy in different burrow types, and (3) compare burrow occupancy among 3 desert regions along a moisture gradient. We hypothesized that burrow occupancy would vary substantially among burrow types, implying differences in quality of sites occupied. Furthermore, we hypothesized that Burrowing Owls would respond to local moisture gradients and that occupancy of burrowing owls during the breeding season would be higher in the wetter, cooler portions of the study area.

\section{Study Area}

The NTS is located in south central Nevada approximately $105 \mathrm{~km}$ northwest of Las Vegas (Fig. 1). The NTS encompasses approximately $3561 \mathrm{~km}^{2}$, and despite some drastic changes (e.g., drill pads with loss of vegetation) to localized areas of the site from more than 40 years of nuclear testing activities, biological resources over much of the NTS remain relatively pristine and undisturbed. The U.S. Department of Energy, National Nuclear Security Administration Nevada Site Office (NNSA/NSO), estimates that only $7 \%$ of the site has been disturbed (USDOE/NV 1996).

The southern two-thirds of the NTS is dominated by 3 large valleys or basins: Yucca Flat, Frenchman Flat, and Jackass Flats. Mountain ridges and hills rise above sloping alluvial fans and enclose these basins. The northern, northwestern, and west central sections of the NTS are dominated by the Pahute and Rainier mesas and the Timber and Shoshone mountains. Elevation on the NTS ranges from $<1000 \mathrm{~m}$ above sea level in Frenchman and Jackass Flats to $>2300 \mathrm{~m}$ on Rainier Mesa.

The NTS has a climate that is characteristic of high deserts (i.e., little precipitation, hot summers, mild winters, and large diurnal temperature ranges). Extreme temperatures in the Mojave Desert (1314 m elevation) were $21{ }^{\circ} \mathrm{C}$ to $-11{ }^{\circ} \mathrm{C}$ in January and $43^{\circ} \mathrm{C}$ to $15^{\circ} \mathrm{C}$ in July. Monthly average temperatures at the NTS range from $7{ }^{\circ} \mathrm{C}$ in January to $32{ }^{\circ} \mathrm{C}$ in July (USDOE 1995). The average annual precipitation on the NTS ranges from $13 \mathrm{~cm}$ at the lower elevations to $23 \mathrm{~cm}$ at the higher elevations (Quiring 1968). Approximately 60\% of this precipitation occurs from September through March.

The NTS contains portions of both the Great Basin Desert and the Mojave Desert, as defined by Jaeger (1957). Transitional areas occur between these 2 distinct deserts, these areas having been created by gradients in precipitation, elevation, temperature, and soil. Unique combinations of physical site conditions have resulted in 10 different vegetation alliances and 20 associations (Ostler et al. 2000). Based on these vegetation alliances, 3 distinct desert regions are recognized: Great Basin desert, Mojave Desert, and Transition (Fig. 1). The Great Basin Desert region $(21 \mathrm{~cm}$ mean annual rainfall) occurs at the higher elevations of the NTS. It is a cold desert with dominant plant species consisting of sagebrush (Artemisia spp.), singleleaf pinyon (Pinus monophylla), and Utah juniper (Juniperus osteosperma). The Transition region (16 cm mean annual rainfall) occurs at the middle elevations of the NTS. Dominant plant species are blackbrush (Coleogyne ramosissima), Nevada jointfir (Ephedra nevadensis), and burrobrush (Hymenoclea salsola). The Mojave Desert region $(13 \mathrm{~cm}$ mean annual rainfall) occurs at the lower elevations of the NTS. It is a hot desert with dominant plant species being creosotebush (Larrea tridentata) and white bursage (Ambrosia dumosa).

\section{Methods}

A burrow site consisted of one or more burrow openings located in the same area, approximately within a 50-m radius. We monitored burrow sites monthly from November 1997 through December 2001, except for July through October 1998, when burrow monitoring was sporadic. Only burrow sites known to be used by Burrowing Owls were monitored. The number of burrow sites we monitored ranged from 24 in November 1997 to 61 in December 2001 due to new burrow sites being found during the study. We selected occupied owl sites for study from historical sighting data (1961-1996), from primary callstop surveys along roads (Steen et al. 1997), and from systematic line surveys $(n=36,100$ $\mathrm{km}, 53$ hours of effort) conducted on foot in natural habitats (Hall et al. 2003).

We made monthly visits to burrow sites to determine owl occupancy. Burrowing Owls and fresh sign (i.e., pellets, scat, feathers, tracks, 


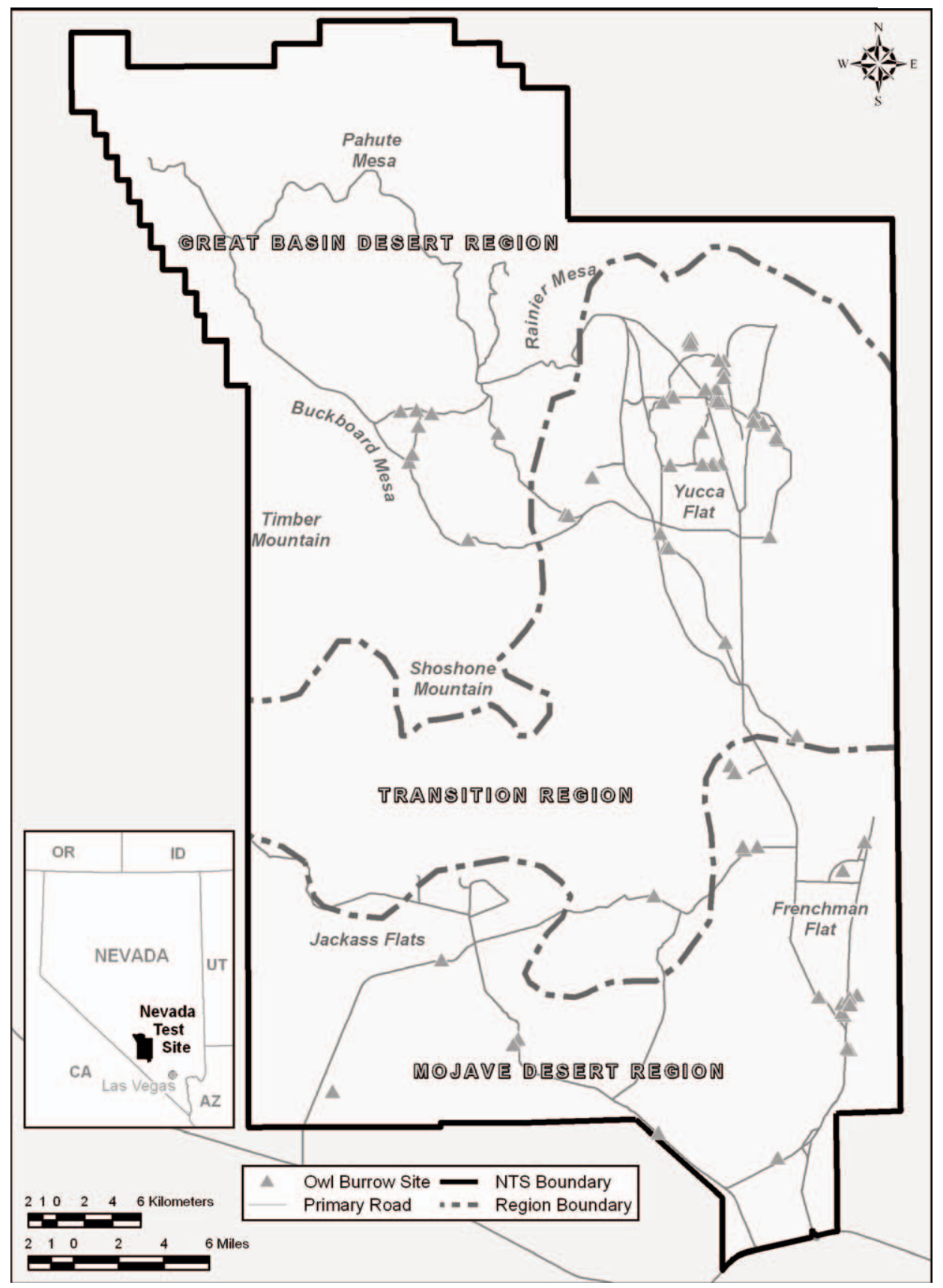

Fig. 1. Map of the Nevada Test Site showing desert region boundaries and burrow sites.

prey remains) on the burrow mound and up to $30 \mathrm{~cm}$ inside the burrow were recorded, and all sign was removed at each visit. We considered burrow sites occupied if one or more individual burrow openings had fresh sign or if owls were present during the visit. We classified each burrow site into one of the following categories: culvert, pipe, culvert-pipe, culvert-earthen, earthen-natural, or earthendisturbed. We recorded only 2 culvert-earthen sites during the study, and the earthen burrows filled in shortly thereafter, so these sites were 


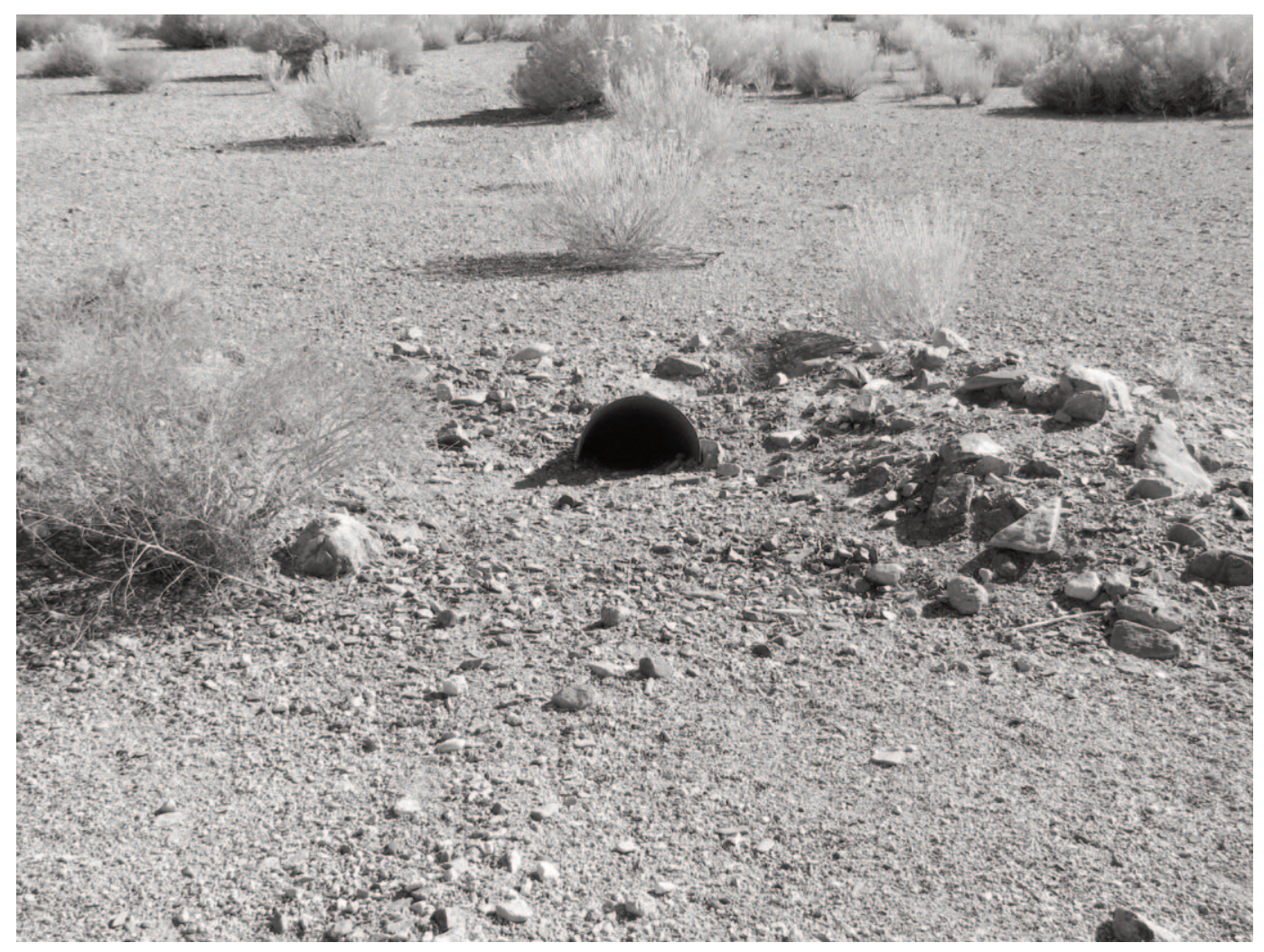

Fig. 2. Typical metal culvert used by Burrowing Owls at the Nevada Test Site (photo by Paul Greger, 22 February 2006).

reclassified as culvert sites. We detected no pipe-earthen sites during the study.

Owls often used metal culverts and pipes in the ground as burrows. Culverts were galvanized-metal, semicircular structures $\left(180^{\circ}\right.$ curvature), some emplaced in the ground up to 40 years ago, under road crossings and on drill pads, to protect buried cables at previous NTS project sites (Fig. 2). We measured all occupied artificial burrow openings (height and width) in the field. Sizes of occupied culverts monitored in this study averaged about $19 \mathrm{~cm}$ high and $34 \mathrm{~cm}$ wide. Pipes at project sites were circular metal or plastic structures that were in the ground with one or more openings exposed to the surface. Pipes monitored on occupied sites typically averaged about 14 $\mathrm{cm}$ high and $16 \mathrm{~cm}$ wide. Culvert-pipe sites consisted of a combination of culvert and pipe burrows on drill pads (Fig. 3). We also monitored earthen burrows on natural and impacted sites. Earthen-natural burrow sites consisted of earthen burrows in areas not disturbed by human activity (e.g., a wash). Earthen-disturbed burrow sites consisted of earthen burrows in disturbed habitat (i.e., areas modified by man, such as road cuts, trenches, pits, and large dirt mounds). We categorized all burrow sites by desert region (Great Basin, Transition, Mojave). Earthen burrows at NTS were typically excavated by desert tortoise (Gopherus agassizii), badger (Taxidea taxus), and kit fox (Vulpes macrotis).

We calculated percent monthly occupancy by desert region for the period November 1998 through December 2001 for regularly monitored sites (38-61 burrow sites) by dividing the number of sites occupied by the number of sites monitored per month in each region and multiplying the quotient by 100. We calculated percent site occupancy by burrow type for a smaller subset of 56 burrow sites (Table 1) that had been monitored for $\geq 7$ months by dividing total months 


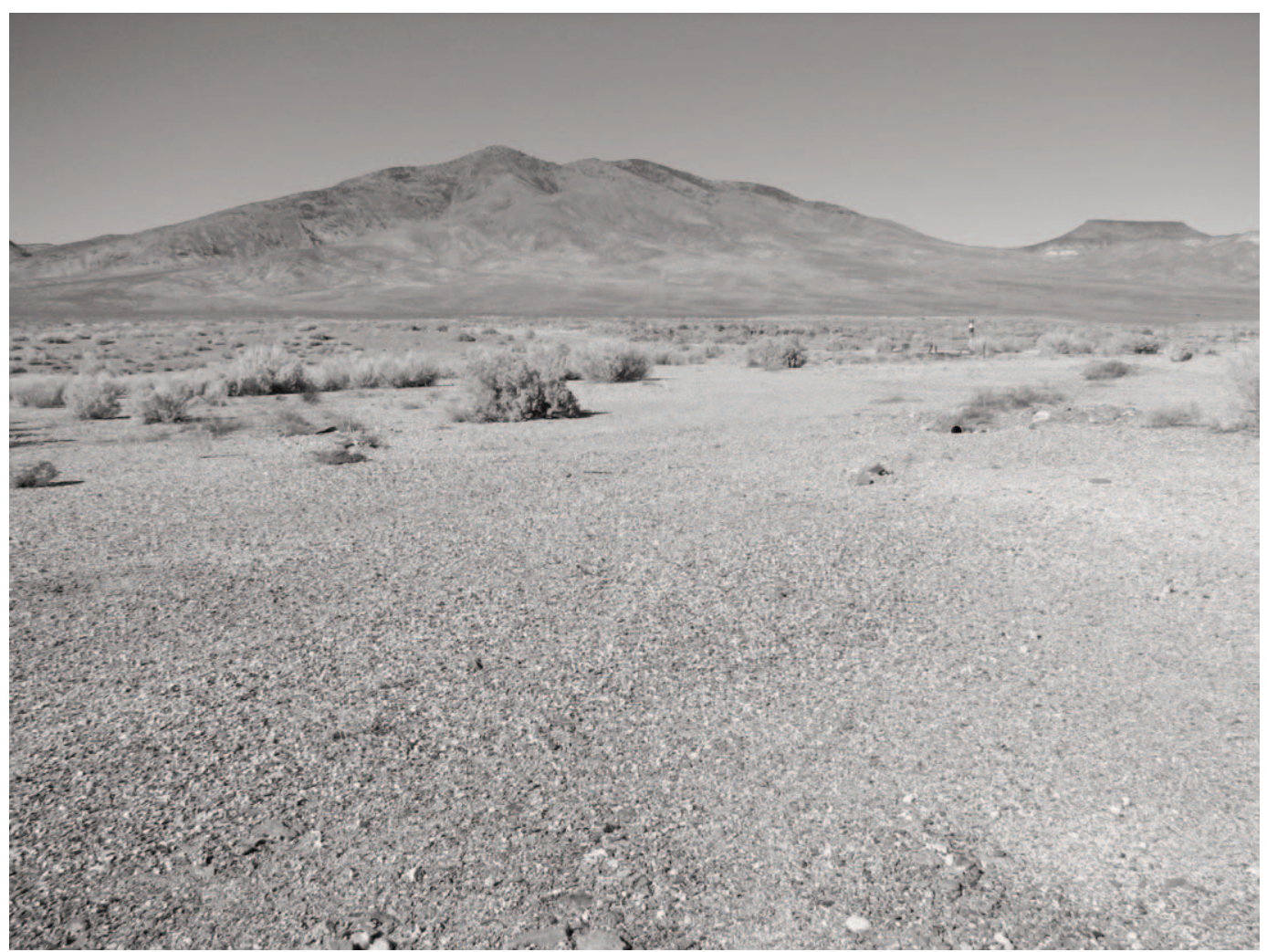

Fig. 3. Typical culvert-pipe burrow site (on a drill pad) used by Burrowing Owls at the Nevada Test Site (photo by Paul Greger, 22 February 2006).

TABLE 1. Number of burrow sites monitored for Burrowing Owl occupancy on the Nevada Test Site by burrow type and desert region.

\begin{tabular}{lccccr}
\hline & \multicolumn{3}{c}{ Desert region } & & \\
\cline { 2 - 4 } Burrow-site type & Great Basin & Mojave & Transition & Total & $\%$ \\
\hline Earthen-natural & 1 & 12 & 4 & 17 & 30.4 \\
Earthen-disturbed & 7 & 2 & 17 & 13 & 23.2 \\
Culvert & & & 7 & 17 & 30.4 \\
Culvert-pipe & & 1 & 1 & 2 & 3.5 \\
Pipe & 8 & 15 & 33 & 56 & \\
Total & & & & \\
\hline
\end{tabular}

occupied by total months monitored, multiplying the quotient by 100 , and averaging percentages by burrow type. We also calculated percent site occupancy by desert region the same as above, both during the owl breeding season (March-August) and the nonbreeding season (September-February), and averaged by desert region. We used ANOVA (general linear model; Minitab version 12, Minitab 1997) to determine significant $(P \leq 0.05)$ differences in occupancy values among burrow types and regions. Pipe burrow sites were excluded from the burrow type analysis because of low sample size $(n=2)$. We used Tukey's mean separation procedure (Minitab $1997)$ to determine which variables were significantly different from each other $(\alpha=$ $0.05)$. Percentage data were arcsine transformed before statistical analysis (Brownlee 1965). 


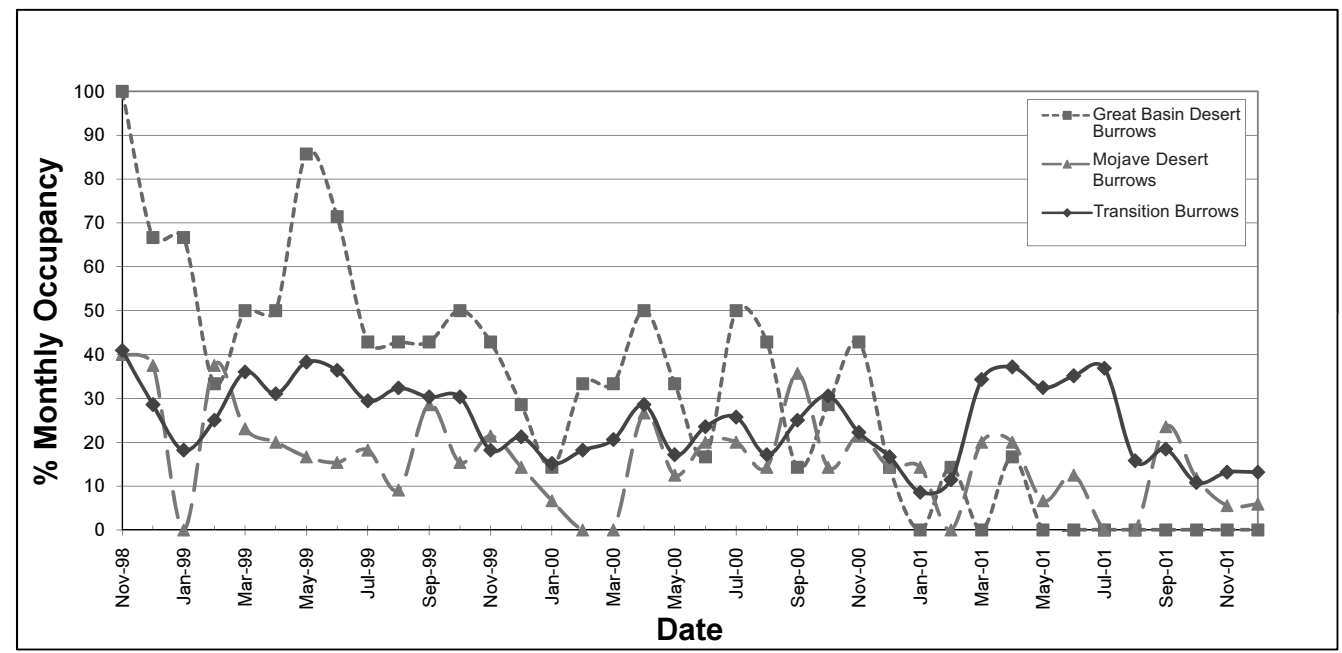

Fig. 4. Percent monthly occupancy of burrow sites by Burrowing Owls, organized by desert region from November 1998 to December 2001 at the Nevada Test Site.

\section{RESULTS}

Percent monthly occupancy by desert region showed distinct patterns of burrow-site use by Burrowing Owls (Fig. 4). Unlike in the Great Basin Desert and Mojave Desert regions, Burrowing Owls or their sign were found in the Transition region during every month of monitoring, and percent monthly occupancy was the most consistent in this region. Initially, percent monthly occupancy in the Great Basin Desert region trended higher than it did in the Transition and Mojave Desert regions, but it declined over time, reaching $0 \%$ in January and March 2001 and remaining there from May-December 2001.

Peaks in percent monthly occupancy occurred during April and May in the Great Basin desert region, during March and April in the Transition region, and from February through April in the Mojave Desert region (Fig. 4). Percent occupancy typically declined at varying rates through the summer and fall, and it was lowest during January and February in the Great Basin Desert and Mojave Desert regions and during January in the Transition region. An exception to this pattern occurred in the Mojave Desert region during September, when percent monthly occupancy peaked in 3 consecutive years.

All of the culvert and culvert-pipe burrow sites occurred in the Transition region, most of the earthen-natural burrow sites occurred in the Mojave Desert region, and earthen-disturbed burrow sites made up most of the sites located in the Great Basin Desert region (Table 1). Seventy percent of the active burrow sites studied were in disturbed habitat, and $30 \%$ were in natural habitat.

We found significant differences $(F=3.89$, $\mathrm{df}=53, P=0.01$ ) for percent site occupancy by burrow type, with culvert-pipe burrow sites being occupied more often than earthen-disturbed or earthen-natural burrow types (Fig. 5). During the breeding period (March-August), differences in percent site occupancy were not statistically significant by region $(F=2.74$, df $=$ $55, P=0.074$; Mojave Desert $=19.4$, Great Basin Desert $=30.8$, and Transition $=39.2$ ), although percent site occupancy averaged nearly $20 \%$ higher in the Transition region than in the Mojave Desert region (Fig. 6). Percent occupancy of owls during the nonbreeding season (September-February) by region was lower in the Great Basin Desert region (27.2) and Transition region (25.5) and slightly higher in the Mojave Desert region (23.3) compared to percent occupancy of owls during the breeding season. Overall, burrow sites were occupied $28.8 \%$ of the time during the study $(n=56$, range $3 \%-100 \%)$.

\section{Discussion}

Results from percent monthly occupancy by region indicated that Burrowing Owls were 


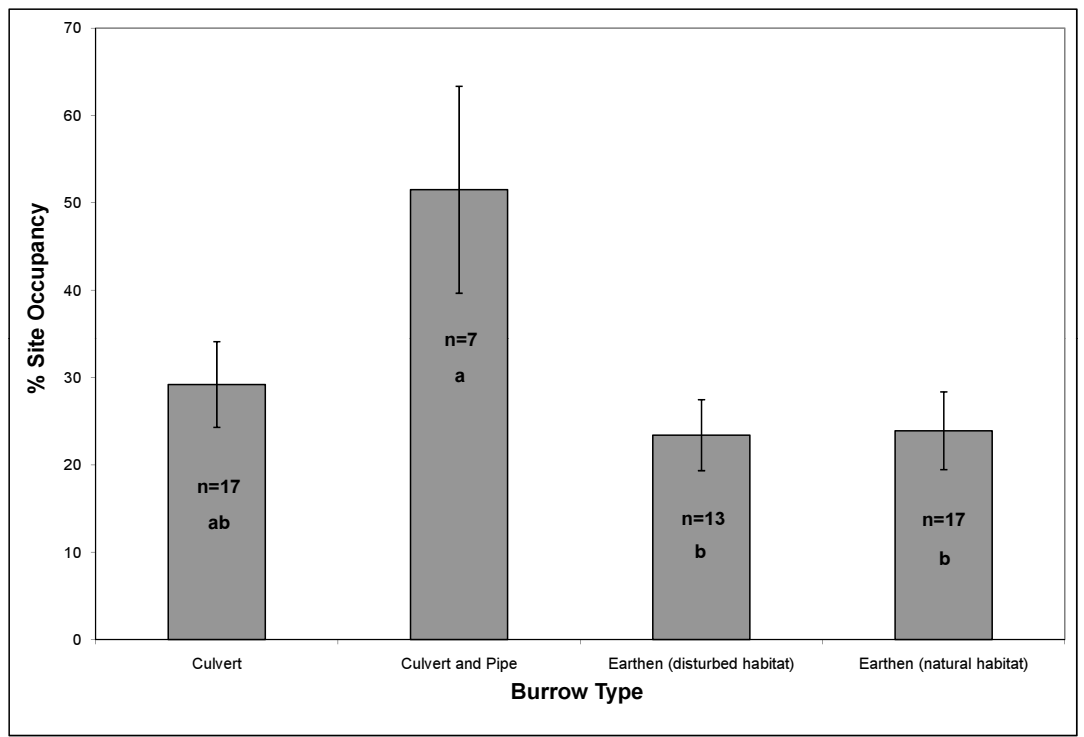

Fig. 5. Percent site occupancy of burrow sites by Burrowing Owls, organized by burrow type at the Nevada Test Site $(n=54$ sites; 2 pipe sites excluded). Different letters indicate significant differences at $\alpha=0.05$, and bars represent one standard error around the mean.

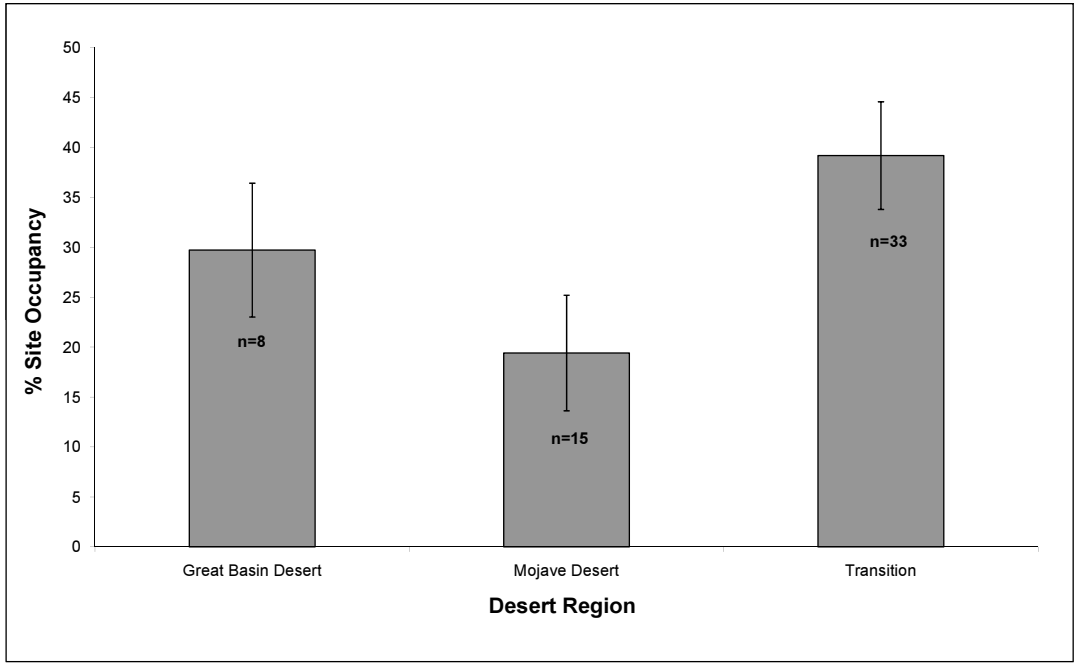

Fig. 6. Percent site occupancy of burrow sites by Burrowing Owls during the breeding season (March through August), organized by desert region on the Nevada Test Site $(n=56$ sites, not significant at $\alpha=0.05)$. Bars represent one standard error around the mean.

present year-round in this area of south central Nevada. Peaks in monthly occupancy during spring may indicate a migration pulse in all regions (Fig. 4), with a tendency in some years (i.e., 1999 and 2001) to follow an elevational and moisture gradient and with peaks occurring earlier in the Mojave Desert region and later in the
Great Basin desert region. The lower occupancy during winter (January-February) suggests that owls may have migrated from the NTS. However, further mark-recapture studies need to be conducted to answer this question in detail.

The decline in owl occupancy after the spring peak may suggest that (1) not all owls 
that moved through the area remained to breed in the region, or (2) owls used multiple burrows over a short time span while searching for suitable breeding burrows. In the Mojave Desert region, a secondary peak in percent monthly occupancy occurred during September for 3 consecutive years (Fig. 4). This peak may have been due to dispersing juveniles searching for their own burrows or due to migrating owls that used burrows in this region as stopover points. Burrowing Owls were always present in the Transition region but not in the Mojave Desert or Great Basin Desert regions. The higher percent monthly occupancy in the Great Basin Desert region may be due to better habitat for birds (Rundel and Gibsen 1996) or may be related to the low number of burrow sites $(n=8)$ monitored. The gradual decline and eventual absence of owls in the Great Basin Desert region remains unexplained but illustrates variability in burrow occupancy and the need for long-term, regular monitoring. One major finding from this study of occupancy is that the NTS may have both resident and migratory owls. Therefore, this area may be an important migratory stopover region in the desert.

Results from percent site occupancy by burrow type imply that culvert-pipe burrow sites were occupied more often by Burrowing Owls than the other 3 burrow types (Fig. 5). These sites were all located on old drill pads (Fig. 3) characterized by sparse vegetation (mostly annual forbs and grasses with widely scattered shrubs) and multiple burrow openings (range $3-11, \bar{x}=6.4$ burrow openings per site). Burrowing Owls may prefer the more-open habitat with numerous burrow openings. All other burrow types averaged about 2 burrows per site or fewer. Our findings are consistent with those of Lantz et al. (2007), that openness of habitat and an abundance of extra burrows within $20 \mathrm{~m}$ (i.e., satellite burrows) were important features at heavily used sites.

Zarn (1974) listed 3 essential factors for good Burrowing Owl habitat: openness, short vegetation, and burrow availability (Best 1969, Coulombe 1971, Butts 1973). Burrowing Owls are also known to select areas with more bare ground and less grass cover than the surrounding area (MacCracken et al. 1985, Green and Anthony 1989, Plumpton and Lutz 1993, Belthoff et al. 1995). More bare ground and lower vegetation may increase an owl's ability to detect predators and may also facilitate prey detection and capture. The presence of satellite burrows in the vicinity of the nest burrow may be a factor in site selection by owls because satellite burrows are used by young birds during nesting and dispersal (King and Belthoff 2001). Predator avoidance may be an important strategy of young owls, accomplished by having numerous burrows near the nest burrow that can be used for escape and dispersal. Below-ground characteristics (e.g., length, depth, internal architecture) were not examined in this study but are likely important for owls selecting a burrow site (Belthoff and King 2002, Lantz et al., 2007).

Percent site occupancy of owls by desert region did not differ significantly among regions (Fig. 6), nor did occupancy mirror the moisture gradient across these regions. Thus, our hypothesis that wetter, cooler areas have higher owl occupancy was not statistically supported. However, the somewhat-higher occupancy in the Transition region (39\%) was likely related to burrow type, since all highuse culvert-pipe burrow sites occurred in this region. In a related study of Burrowing Owl breeding on the NTS, Hall et al. (2003) found that the greatest numbers of breeding pairs and young consistently occurred in the Transition region (i.e., Yucca Flat), which had the most productive breeding habitat for Burrowing Owls on the NTS.

Metal culverts as described in this study may prove to be a cost-effective material for construction of artificial Burrowing Owl burrows in desert ecosystems. Once installed, culverts don't cave in, as numerous earthen burrows did in this study, and if culverts are filled in, fossorial animals can re-excavate them, and they can be reused by owls. These culvert structures would be durable, would require no maintenance, and would be long lasting.

Because of the large area at the NTS and the overall low abundance of Burrowing Owls in this region, detecting suitable numbers of this species proved challenging. Seventy percent of the active burrow sites that we studied were in disturbed habitat, and only $30 \%$ were in natural habitat. Although we made searches for owls in natural areas, our searches often were made in areas near roads; thus, our data were probably biased toward roads and associated disturbances. Therefore, we believe that more natural Burrowing Owl 
sites probably exist than were identified by this study. However, we believe our results and conclusions are still valid from the sites we selected for study. Future owl surveys could give a better idea of overall owl distribution by including other natural areas and western regions of the NTS that were undersampled.

We documented year-round occupancy patterns of Burrowing Owls over multiple years and revealed patterns of occupancy among 3 desert regions, demonstrated that burrow occupancy was highest in culvert-pipe burrow sites, and illustrated that metal culverts are long lasting and are commonly used as breeding sites. We suggest that owl occupancy is influenced greatly by suitable burrows associated with open areas of habitat with low vegetation and that occupancy is influenced to a lesser degree by climatic regime.

\section{ACKNOWLEDGMENTS}

We thank Ashley V. Cushman, Jenny L. Bishop, and Khara Kaumans for assistance with field-data collection and the U.S. Department of Energy's National Nuclear Security Administration Nevada Site Office, which provided funding for ecological monitoring at NTS under contract number DE-AC08-96NV11718. This manuscript has been authored by National Security Technologies, LLC, under contract number DE-AC52-06NA25946 with the U.S. Department of Energy. The United States Government retains and the publisher, by accepting the article for publication, acknowledges that the United States Government retains a nonexclusive, paid-up, irrevocable worldwide license to publish or reproduce the published form of this manuscript, or allow others to do so, for the United States Government purposes. Kent Ostler and Dennis Hansen provided helpful reviews of the manuscript.

\section{Literature Cited}

Belthoff, J.R., AND A.R. KIng. 1997. Between-year movements and nest burrow use by Burrowing Owls in southwestern Idaho: 1996 annual report. Technical Bulletin No. 97-3, Bureau of Land Management, Boise.

2002. Nest-site characteristics of Burrowing Owls (Athene cunicularia) in the Snake River Birds of Prey Area, Idaho, and applications to artificial burrow installation. Western North American Naturalist 62:112-119.

Belthoff, J.R., A.R. King., K. Doremus, and T. Smith. 1995. Monitoring post fledgling Burrowing Owls in southwestern Idaho. Technical Bulletin No. 95-8, Bureau of Land Management, Boise.

Belthoff, J.R., And B.W. Smith. 2003. Patterns of artificial burrow occupancy and reuse by Burrowing Owls in Idaho. Wildlife Society Bulletin 31:138-144.

BEST, R. 1969. Habitat, annual cycle and food of Burrowing Owl in southwestern New Mexico. Master's thesis, New Mexico State University, Las Cruces. $34 \mathrm{pp}$.

Botelho, E.S., AND P.C. ARRowood. 1996. Nesting success of Western Burrowing Owls in natural and human-altered environments. Pages 61-68 in D.M. Bird, D.E. Varland, and J.J. Negro, editors, Raptors in human landscapes: adaptations to built and cultivated environments. Academic Press, San Diego, CA.

1998. The effect of burrow site use on the reproductive success of a partially migratory population of Western Burrowing Owls (Speotyto cunicularia hypugaea). Journal of Raptor Research 32:233-240.

BrownleE, K.A. 1965. Statistical theory and methodology in science and engineering. 2nd edition. Wiley, New York.

ButTs, K.O. 1973. Life history and habitat requirements of Burrowing Owls in western Oklahoma. Master's thesis, Oklahoma State University, Stillwater. 188 pp.

Coulombe, H.N. 1971. Biology and population ecology of the Burrowing Owl, Speotyto cunicularia, in the Imperial Valley of California. Condor 73:162-176.

Desmond, M.J., J.A. SAVIDge, AND K.M. Eskridge. 2000. Correlations between Burrowing Owl and blacktailed prairie dog declines: a 7-year analysis. Journal of Wildlife Management 64:1067-1075.

Green, G.A., And R.G. Anthony. 1989. Nesting success and habitat relationships of Burrowing Owls in the Columbia Basin, OR. Condor 91:347-354.

Hall, D.B., P.D. Greger, AV. Cushman, and C.A. Wills. 2003. Ecology of the Western Burrowing Owl on the Nevada Test Site. DOE/NV/11718-701. Bechtel Nevada, Las Vegas, NV.

Holmes, A.L., G.A. Green, R.L. Morgan, and K.B. LivezEY. 2003. Burrowing Owl nest success and burrow longevity in north central Oregon. Western North American Naturalist 63:244-250.

JAEgER, E.C. 1957. The North American deserts. Stanford University Press, Stanford, CA. 308 pp.

King, R.A., And J.R. Belthoff. 2001. Post-fledging dispersal of Burrowing Owls in southwestern Idaho: characteristics of movements and use of satellite burrows. Condor 103:118-126.

Klute, D.S., L.W. Ayers, M.T. Green, W.H. Howe, S.L. Jones, J.A. Shaffer, S.R. Sheffield, And T.S. ZimMERMAN. 2003. Status assessment and conservation plan for the Western Burrowing Owl in the United States. U.S. Department of Interior, Fish and Wildlife Service, Biological Technical Publication FWS/BTP-R6001-2003, Washington, DC.

Lantz, S.J., C.J. Conway, and S.H. Anderson. 2007. Multiscale habitat selection by Burrowing Owls in black-tailed prairie dog colonies. Journal of Wildlife Management 71:2664-2672.

Lutz, R.S., And D.L. Plumpton. 1999. Philopatry and nest site reuse by Burrowing Owls: implications for productivity. Journal of Raptor Research 33:149-153.

MacCracken, J.G., D.W. Uresk, and R.M. Hansen. 1985. Vegetation and soils of Burrowing Owl nest 
sites in Conata Basin, South Dakota. Condor 87: $152-154$.

Minitab. 1997. Minitab user's guide 2: data analysis and quality tools. Release 12. Minitab, Inc., State College, PA.

Ostler, W.D., D.J. Hansen, D.C. Anderson, and D.B. HaLL. 2000. Classification of vegetation on the Nevada Test Site. DOE/NV/11718-477 [December 2000], Las Vegas, NV.

Plumpton, D.L., AND R.S. Lutz. 1993. Prey selection and food habits of Burrowing Owls in Colorado. Great Basin Naturalist 53:299-304.

QUiRING, R.F. 1968. Climatological data, Nevada Test Site and Nuclear Rocket Development Station. ESSA Technical Memorandum ARL-7, Environmental Sciences Service Administration, U.S. Department of Commerce, Las Vegas, NV.

RICH, T. 1984. Monitoring Burrowing Owl populations: implications of burrow re-use. Wildlife Society Bulletin 12:178-180.

1986. Habitat and nest-site selection by Burrowing Owls in the sagebrush steppe of Idaho. Journal of Wildlife Management 50:548-555.

Rundel, P.W., AND A.C. Gibson. 1996. Ecological communities and processes in a Mojave Desert ecosystem: Rock Valley, Nevada. Cambridge University Press, Cambridge, Great Britain. 369 pp.
Steen, D.C., D.B. Hall, P.D. Greger, and C.A. Wills. 1997. Distribution of the chuckwalla, Western Burrowing Owl, and six bat species on the Nevada Test Site. DOE/NV/11718-49, U.S. Department of Energy, Nevada Operations Office, Las Vegas.

Thomsen, L. 1971. Behavior and ecology of Burrowing Owls on the Oakland Municipal Airport. Condor 73:177-192.

U.S. Department of Energy. 1995. Final programmatic environmental impact statement for tritium supply and recycling. Volumes 1 and 2. DOE/EIS-0161, U.S. Department of Energy, Office of Reconfiguration, Washington, DC.

[USDOE/NV] U.S. Department of Energy, Nevada Operations Office. 1996. Final environmental impact statement for the Nevada Test Site and off-site locations in the state of Nevada. Volume 1, chapters 1-9. DOE/EIS 0243 [August 1996], Las Vegas, NV.

ZARN, M. 1974. Habitat management series for unique or endangered species. Owl report number 11, Bureau of Land Management, Denver, CO.

Received 7 March 2008 Accepted 3 February 2009 